\title{
Patient satisfaction with colonoscopy: A literature review and pilot study
}

\author{
Lucas Chartier ${ }^{1}$, Erin Arthurs BSc${ }^{1}$, Maida J Sewitch PhD²
}

\begin{abstract}
L Chartier, E Arthurs, MJ Sewitch. Patient satisfaction with colonoscopy: A literature review and pilot study. Can J Gastroenterol 2009;23(3):203-209.
\end{abstract}

BACKGROUND: Current guidelines recommend that colonoscopic colorectal cancer screening be undertaken every 10 years after the age of 50 years. However, because the procedure does not meet criteria that promote screening uptake, patient satisfaction with colonoscopy may encourage repeat screening.

OBJECTIVE: To systematically review the literature and conduct a pilot study of patient satisfaction with the colonoscopy experience. METHODS: All cohort studies from January 1997 to August 2008 in the MEDLINE database that measured either patient satisfaction with colonoscopy, patient willingness to return for colonoscopy under the same conditions or patient preference for colonoscopy compared with other large bowel procedures were identified. The search was supplemented by journal citation lists in the retrieved articles.

RESULTS: Of the 29 studies identified, 15 met the inclusion criteria. Consistently, the vast majority of patients (approximately 95\%) were very satisfied with their colonoscopy experience. Patient satisfaction was similar for screening and nonscreening colonoscopy. Patient willingness to return for the procedure ranged from $73 \%$ to $100 \%$. Of the five studies that examined modality preference, three studies reported the majority of patients preferred colonography to colonoscopy and two studies reported the reverse. Our pilot study findings mirrored those of other studies that were conducted in the United States. The major limitation of the included studies was that patients who were most dissatisfied may have gone elsewhere to have their colonoscopy. CONCLUSIONS: Patients were very satisfied with colonoscopy. The majority were willing to return for repeat testing under the same conditions, and colonoscopy was not preferred over other modalities. However, studies were limited by methodological shortcomings.

Key Words: Colonography; Colonoscopy; Patient preference; Patient satisfaction; Review; Willingness to return

$\mathrm{C}$ olorectal cancer (CRC) is the second leading cause of cancer deaths in Canada (1). CRC screening reduces the incidence of morbidity and mortality from $\mathrm{CRC}$ by the removal of precursor adenomatous polyps and the detection and treatment of early stage cancers, respectively $(2,3)$. Canadian and American guidelines recommend CRC screening in persons 50 years of age and older without other identifiable risk factors for developing CRC (considered to be average risk). While there are four currently recommended screening modalities the fecal occult blood test, flexible sigmoidoscopy, double contrast barium enema and colonoscopy - colonoscopy is considered to be optimal because it provides a view of the entire colon and an opportunity for therapeutic intervention (4-8).

\section{Satisfaction des patients à l'endroit de la colonoscopie : Revue de la littérature et étude pilote}

HISTORIQUE : Les lignes directrices actuelles recommandent un dépistage du cancer colorectal par colonoscopie tous les dix ans. Toutefois, étant donné que l'intervention ne répond pas aux critères qui favorisent l'adoption à grande échelle d'un tel dépistage, la satisfaction des patients à l'endroit de la colonoscopie pourrait encourager la fidélité aux examens périodiques.

OBJECTIF : Faire une revue systématique de la littérature et procéder à une étude pilote sur la satisfaction des patients à l'endroit de la colonoscopie.

MÉTHODE : Dans la base de données MEDLINE, les auteurs ont repéré toutes les études cohortes de janvier 1997 à août 2008 qui mesuraient la satisfaction des patients à l'égard de la coloscopie, la volonté des patients de subir une nouvelle coloscopie dans les mêmes conditions ou la préférence des patients pour la coloscopie par rapport à d'autres interventions du gros intestin. Les auteurs ont complété leur interrogation avec les listes bibliographiques présentées dans les articles recensés.

RÉSULTATS : Parmi les 29 études relevées, 15 répondaient aux critères d'inclusion. Dans tous les cas, la grande majorité des patients (environ 95 \%) se sont dits très satisfaits de leur colonoscopie. La satisfaction des patients s'est révélée similaire pour les colonoscopies de dépistage et autres. La volonté des patients à se présenter de nouveau pour la même intervention variait de $73 \%$ à $100 \%$. Parmi les cinq études qui se sont penchées sur les préférences des patients pour les différentes modalités, trois ont signalé que la majorité des patients préféraient la colonographie à la colonoscopie et deux ont mentionné l'inverse. Les résultats de notre étude pilote font écho à d'autres études qui ont été réalisées aux ÉtatsUnis. Le principal inconvénient des études incluses est que les patients qui se sont dits insatisfaits ont peut-être subi leur colonoscopie ailleurs.

CONCLUSIONS : Les patients ont été très satisfaits de leur colonoscopie. La majorité se disaient prêts à subir de nouveau l'épreuve dans les mêmes conditions et la colonoscopie n'a pas été préférée à d'autres modalités. Toutefois, on a reproché aux études certaines lacunes méthodologiques.

According to current screening guidelines, colonoscopy should be performed every 10 years after the age of 50 years (9-11). Despite universal health care in Canada, CRC screening rates are suboptimal $(12,13)$ and more than two-thirds of people with CRC present when the disease is symptomatic (14).

The use of colonoscopy as a primary CRC screening modality is controversial. In the current environment of limited financial, health care and human resources, there are ethical concerns that higher-risk individuals will be denied timely access to colonoscopy because of longer wait times. Moreover, colonoscopy does not meet the screening modality criteria for a successful screening program, which includes wide availability, low cost, ease of administration and minimal discomfort

${ }^{1}$ Division of Clinical Epidemiology, Research Institute of the McGill University Health Centre; ${ }^{2}$ Department of Medicine, McGill University, Montreal, Quebec

Correspondence: Dr Maida J Sewitch, 687 Pine Avenue West, V-Building, The Royal Victoria Hospital, Montreal, Quebec

H3A 1A1. Telephone 514-934-1934 ext 44736, fax 514-934-8293, e-mail maida.sewitch@mcgill.ca

Received for publication March 31, 2008. Accepted October 10, 2008 
$(15,16)$. In fact, colonoscopy is invasive and is commonly associated with anxiety, embarrassment and pain. Additionally, bowel preparation and the effects of sedation may disrupt the patient's performance of normal daily activities. Patient compliance with screening colonoscopy, an important determinant of an effective screening program (17), is challenging, especially in the context of repeat testing.

Patient satisfaction with colonoscopy may be related to patient compliance, because in health care, patient satisfaction is often a good predictor of patient adherence to physicianrecommended treatments or tests. In current colonoscopy practice, unsedated colonoscopy (18), long wait times that can range from 26 to 208 days (19) and inadequate information given preprocedurally (20) may negatively affect patient satisfaction. Because an unsatisfactory colonoscopy screening experience may discourage repeat screening, we reviewed studies that assessed satisfaction with the total colonoscopy experience by patients undergoing screening colonoscopy. Findings from our pilot study are also presented to understand the impact of the increased demand and limited resources for colonoscopy on patient satisfaction, and to compare levels of patient satisfaction in Canada and the United States. The findings may provide decision and policy makers with a framework for developing effective CRC screening programs.

\section{METHODS}

A MEDLINE search for articles published between January 1997 and August 2008 was conducted using the following subject headings or keywords: "mass screening" AND "colonoscopy" OR "colorectal neoplasm" AND "personal satisfaction" OR "satisfaction". Additional articles were retrieved after manual examination of the reference sections of the initial articles.

\section{Inclusion and exclusion criteria}

Prospective cohort studies were included if patient satisfaction with colonoscopy, patient willingness to return for colonoscopy under the same conditions or patient preference for colonoscopy compared with other large bowel procedures was examined. Studies were excluded if the satisfaction assessment focused on specific aspects of the colonoscopy experience (eg, pain or sedation [21-24]); if the preference assessment occurred before performing the colonoscopy procedure (25-29) or if interventions to improve patient satisfaction were tested (20,30-32). Studies published before 1997 were also excluded because the colonoscopic CRC screening guidelines for average-risk individuals were not published until 1997 (33) and colonoscopies performed before this year would likely have not been for screening purposes. Furthermore, recent improvements in colonoscopes make the findings of older studies less relevant in the context of today's standard of care (34-38) because newer colonoscopes, which are more flexible and induce less pain compared with their predecessors (39), may increase patient satisfaction.

\section{Quality score}

The methodological quality of the studies included in the present review was scored using a grading scheme based on four criteria deemed relevant to the research question. These criteria were the following:

- The inclusion of persons 50 years of age and older, because this is the recommended age at which to begin CRC screening (9-11);
- The method of assessing patient satisfaction was reported;

- The timing of the patient satisfaction assessment was reported; and

- The patient sample was restricted to those undergoing screening procedures because less importance may be placed on satisfaction for procedures that are performed for diagnostic purposes.

Accordingly, a four-point scale was created (1 to 4), with lower scores indicating better methodological quality. Category 1 was defined as studies fulfilling the four criteria; category 2 was defined as studies fulfilling three of the four criteria; category 3 was defined as fulfilling one or two of the four criteria; and category 4 was defined as not fulfilling any of the designated criteria.

\section{RESULTS}

Based on the selection criteria, 15 studies were retained for the present review; the characteristics of these studies are summarized in Table 1 . The median methodological quality score was 3 (range 1 to 4 ). Three studies (40-42) met category 1 criteria. Although Bosworth et al (43) did not target persons 50 years of age and older, the data were analyzed specifically for the average-risk population (category 2). One study (44) was classified as category 4 because none of the criteria were described or applicable. Although the study design variables were reported in eight studies (45-52), they were classified as category 3 because the population was not restricted to persons 50 years of age and older and to those undergoing screening colonoscopy. The remaining three studies were classified as category 2; two $(43,53)$ did not restrict their populations to those with screening colonoscopy and one study (54) targeted patients 18 years of age and older. Overall, four studies $(45,46,48,52)$ did not report information on the indication for the procedure. Sedation was given to $100 \%$ of patients in seven studies $(41,43,48-50,53,54)$, and to none of the patients in three studies $(44,47,51)$ (ie, the focus was unsedated colonoscopy). In three studies $(40,42,45)$, the proportion of sedated patients was not detailed, and in two studies, $81 \%$ (52) and 99\% (46) of patients, respectively, were sedated.

\section{Study methods}

Some studies used more than one method to assess patient satisfaction. Four studies $(41,43,46,53)$ implemented satisfaction questionnaires that were assessed for both validity and reliability. Seven studies $(43,45,46,48-50,52)$ assessed patient satisfaction with the use of a 4- or 7-point rating or Likert scale, or a $10 \mathrm{~cm}$ visual analogue scale. Five studies $(40,43,50,53,54)$ used the method of 'colonoscopy preference over other modalities' (ie, air contrast barium enema and computed tomographic [CT] colonography). In nine studies $(41,43,44,46-49,51,52)$, patients were asked whether they would be willing to undergo another colonoscopy under the same conditions.

Timing of patient satisfaction in relation to undergoing the colonoscopy differed across studies. Patients underwent a colonoscopy and immediately afterwards rated their satisfaction and/or their willingness to return in eight studies $(41,42,44,46-48,51,52)$. In three studies $(50,53,54)$, each participant underwent same-day CT colonography and colonoscopy, and rated satisfaction and willingness to return after each procedure and/or preference of modality several days to weeks later. In the study by Kim et al (49), patients underwent either 
TABLE 1

Characteristics of selected studies

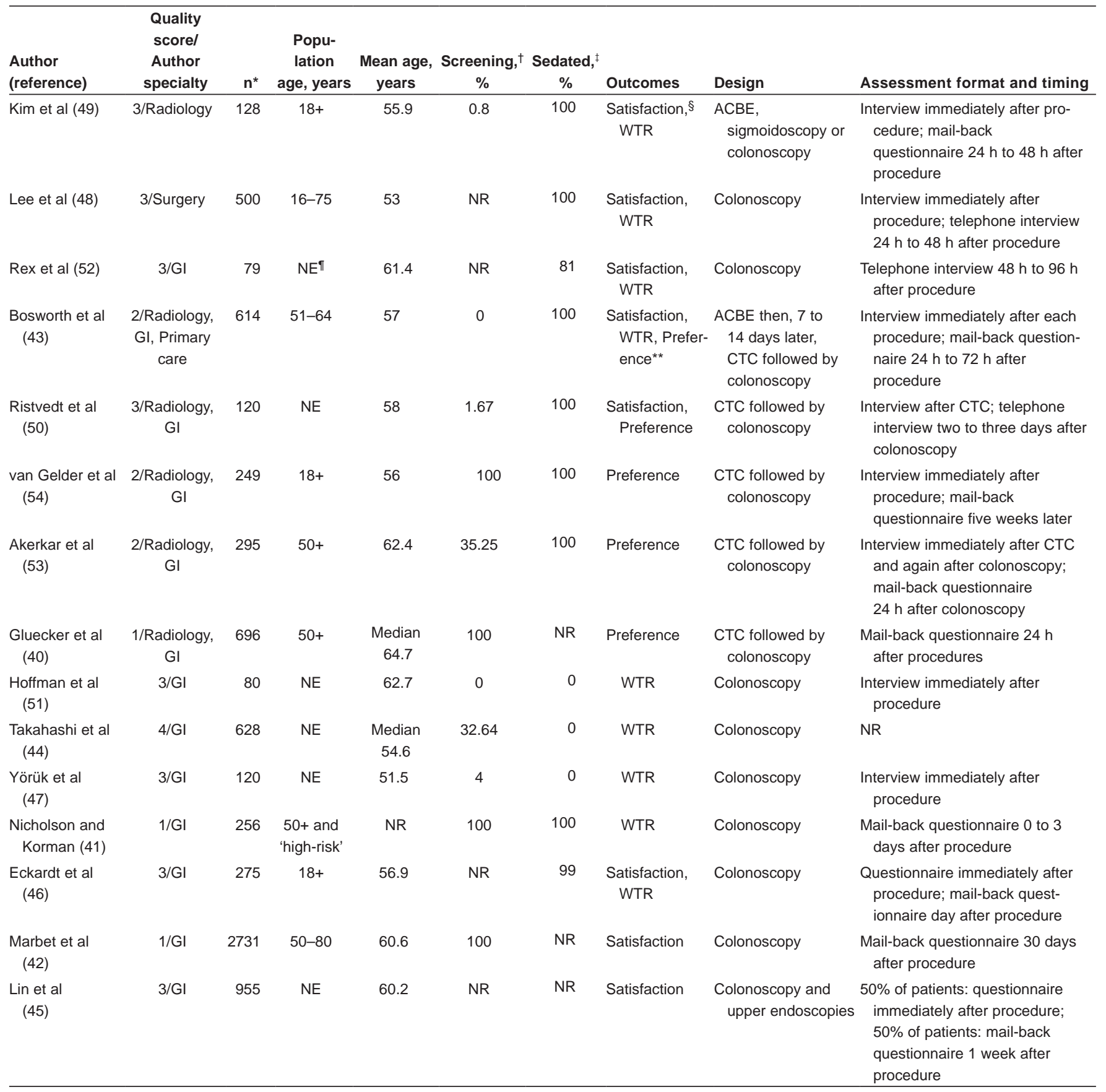

${ }^{*}$ Number of participants that underwent colonoscopy; ${ }^{\dagger}$ Percentage of colonoscopies that were screening colonoscopies; ${ }^{\ddagger}$ Percentage of patients that were sedated for their colonoscopies; ' SSatisfaction with colonoscopy; " $N E$ No exclusion, in which the study did not have age restrictions; **Preference for one modality versus other procedure. ACBE Air contrast barium enema; CTC Computed tomographic colonography; GI Gastroenterology; NR Not reported; WTR Willingness to return for the same procedure under the same conditions

air contrast barium enema, sigmoidoscopy or colonoscopy and rated satisfaction and willingness to return immediately after the procedure. In the study by Bosworth et al (43), all patients underwent all three procedures (air contrast barium enema, colonoscopy and CT colonography) at different times, and rated satisfaction and willingness to return immediately following each procedure; preference of modality was assessed $24 \mathrm{~h}$ to $72 \mathrm{~h}$ after the third procedure was performed. In the study by Lin et al (45), patients underwent a colonoscopy in which one- half rated their satisfaction immediately after the procedure and the other one-half during the following week.

The method of questionnaire administration varied as well. Five studies $(47,48,50-52)$ assessed patient satisfaction using face-to-face or telephone interviews. Three studies (40-42) used mail-back questionnaires. Six studies $(43,45,46,49,53,54)$ used both interview and mail-back questionnaires. Takahashi et al (44) did not describe either the method or the timing of the patient satisfaction assessment. 
TABLE 2

Summary of study results

\begin{tabular}{|c|c|c|c|}
\hline Author (reference) & Outcome & Findings & Comparator \\
\hline \multirow[t]{2}{*}{ Kim et al (49) } & Satisfaction & $\begin{array}{l}\text { Overall satisfaction was similar for } \\
\text { ACBE, sigmoidoscopy, colonoscopy }\end{array}$ & $\begin{array}{l}\text { 7-point rating scale: "How satisfied were you with the procedure } \\
\text { overall?" 1: 'Satisfied' - 7: 'Dissatisfied' }\end{array}$ \\
\hline & WTR & $\begin{array}{l}\text { OR:1.82 (95\% CI 1.07-3.09): ABCE } \\
\text { patients more likely to be NOT } \\
\text { WILLING to return compared to } \\
\text { colonoscopy patients; OR: } 1.02 \\
\text { (95\% CI 0.66-1.57): No difference } \\
\text { between sigmoidoscopy and } \\
\text { colonoscopy }\end{array}$ & $\begin{array}{l}\text { 7-point rating scale: "If it were advised by your doctor, how willing } \\
\text { would you be to undergo this test again?" 1: 'Very willing' - 7: 'Not } \\
\text { willing' }\end{array}$ \\
\hline \multirow[t]{2}{*}{ Lee et al (48) } & Satisfaction & Mean score: 7.2 & 10 cm visual analogue scale: 0: 'Not satisfied' - 10: 'Very satisfied'. \\
\hline & WTR & $78.4 \%$ & $\begin{array}{l}\% \text { willing to repeat patient controlled sedation for colonoscopy } \\
\text { (yes or no) }\end{array}$ \\
\hline \multirow[t]{2}{*}{ Rex et al (52) } & Satisfaction & 95.7\% "very satisfied" & $\begin{array}{l}\text { Question not reported. Satisfaction rated as either 'somewhat satisfied' } \\
\text { or 'very satisfied' }\end{array}$ \\
\hline & WTR & $100 \%$ & $\%$ willing to return to the same colonoscopist (yes or no) \\
\hline \multirow[t]{3}{*}{ Bosworth et al (43) } & Satisfaction & $\begin{array}{l}\text { Mean score: colonoscopy: 1.81; } \\
\text { ACBE: } 2.11 \text {; CTC: } 1.94\end{array}$ & $\begin{array}{l}\text { Question not reported. 5-point Likert scale: 1: 'Totally agree' - 5: 'Totally } \\
\text { disagree' }\end{array}$ \\
\hline & WTR & $\begin{array}{l}\text { Mean score: colonoscopy: } 1.78 \\
\text { ACBE: } 2.08 ; \text { CTC: } 1.90\end{array}$ & $\begin{array}{l}\text { Question not reported. 5-point Likert scale: 1: 'Totally agree' - 5: 'Totally } \\
\text { disagree' }\end{array}$ \\
\hline & Preference & $\begin{array}{l}\text { Preference for colonoscopy compared } \\
\text { with CTC }\end{array}$ & Deduced from ratings for three procedures \\
\hline \multirow[t]{2}{*}{ Ristvedt et al (50) } & Satisfaction & $\begin{array}{l}95 \% \text { rated colonoscopy 'not unpleasant' } \\
\text { or 'a little unpleasant' }\end{array}$ & $\begin{array}{l}\text { Question not reported. Satisfaction ranked as: 'Not unpleasant', 'A little } \\
\text { unpleasant', 'Somewhat unpleasant', 'Very unpleasant', 'Extremely } \\
\text { unpleasant' }\end{array}$ \\
\hline & Preference & $\begin{array}{l}\text { 14.2\% colonoscopy; } 57.5 \% \text { СТC; } \\
\text { 28.3\% no preference }\end{array}$ & \% who preferred CTC/colonoscopy \\
\hline van Gelder et al (54) & Preference & $\begin{array}{l}\text { 71\% preferred CTC to colonoscopy } \\
\text { immediately after procedure; } 61 \% \text { pre- } \\
\text { ferred CTC to colonoscopy } 5 \text { weeks } \\
\text { following the procedure }\end{array}$ & \% who chose CTC/colonoscopy for next examination \\
\hline \multirow[t]{2}{*}{ Akerkar et al (53) } & Preference & $63.7 \%$ preferred colonoscopy to СTC & \% who preferred CTC/colonoscopy \\
\hline & & $\begin{array}{l}69.1 \% \text { who preferred colonoscopy had } \\
\text { a strong preference }\end{array}$ & $\begin{array}{l}\text { \% strongly preferred colonoscopy: "Rate how strongly you preferred } \\
\text { colonoscopy" } 1 \text { : 'Strong preference' - 7: 'Least preference' }\end{array}$ \\
\hline Gluecker (40) & Preference & $72.3 \%$ preferred CTC to colonoscopy & \% who preferred CTC/colonoscopy \\
\hline Hoffman et al (51) & WTR & $73 \%$ & $\begin{array}{l}\% \text { 'willing to undergo another colonoscopy, if medically indicated, } \\
\text { without premedication' }\end{array}$ \\
\hline Takahashi et al (44) & WTR & $98.2 \%$ & Question not reported. \% willing to undergo future colonoscopy \\
\hline Yörük et al (47) & WTR & $88 \%$ & $\begin{array}{l}\text { Question not reported. \% willing to undergo colonoscopy again without } \\
\text { sedation }\end{array}$ \\
\hline Nicholson and Korman (41) & WTR & $99 \%$ & Question not reported. \% willing to have procedure again \\
\hline \multirow[t]{2}{*}{ Eckardt et al (46) } & Satisfaction & $\begin{array}{l}98 \% \text { agreement to satisfaction state- } \\
\text { ment; mean score: } 1.36\end{array}$ & $\begin{array}{l}\text { 5-point Likert scale: "I was very satisfied with the care I received" } \\
\text { 1: 'Strongly agree' - 5: 'Strongly disagree' }\end{array}$ \\
\hline & WTR & 92\% agreement to WTR statement & $\begin{array}{l}\text { 5-point Likert scale: "I would be willing to repeat the exam in the future } \\
\text { in necessary" 1: 'Strongly agree' - 5: 'Strongly disagree' }\end{array}$ \\
\hline Marbet et (42) & Satisfaction & $91.3 \%$ & Question not reported \\
\hline Lin et al (45) & Satisfaction & Mean score: 6.74 & $\begin{array}{l}\text { 7-point Likert scale: "I am satisfied with my overall experience here for } \\
\text { the procedure" 1: 'Strongly disagree' - 7: 'Strongly agree' }\end{array}$ \\
\hline
\end{tabular}

Satisfaction Satisfaction with colonoscopy; Preference Preference of colonoscopy versus other procedures; WTR Willingness to return for same procedure under the same conditions (\% yes). ACBE Air contrast barium enema; CTC Computed tomographic colonography

\section{Satisfaction with colonoscopy}

Given the various measures of satisfaction used (Table 2), means and proportions of satisfied patients were reported. Three studies used rating scales with 1 being the most satisfied; one study (52) found that $96 \%$ of patients rated 1 out of 4 , another found that $95 \%$ rated 1 or 2 out of 5 (50), and the third found a mean rating of $1.36 \pm 0.52$ (46). Using a 5-point
Likert scale, Bosworth et al (43) found a mean score of 1.81, in which 1 indicated 'in total agreement with being satisfied'. Lee et al (48), using a $10 \mathrm{~cm}$ visual analogue scale with 10 being the most satisfied, found a mean rating of $7.2 \pm 2.6 \mathrm{~cm}$. Lin et al (45) used a 7-point rating scale with 7 being the most satisfied, and reported a mean score of $6.74 \pm 0.76$. Kim et al (49) reported nonstatistically significant ORs to represent the likelihood that 
patients would report a higher score for one test (colonoscopy) compared with another procedure (sigmoidoscopy or air contrast barium enema) indicating similar results for the three modalities (Table 2). Seven studies (41-44,47,50,52) did not report the questionnaire items, although Ristvedt et al (50) assessed levels of agreement as to how 'unpleasant' the procedure was.

\section{Willingness to return}

Nine studies $(41,43,44,46-49,51,52)$ assessed willingness to return for the same procedure under the same conditions (Table 2). In these studies, the proportion of patients willing to return ranged from $73 \%$ to $100 \%$. Using a 5-point Likert scale with 1 being 'in total agreement with willingness to return', one group (43) found a mean score of 1.78 . Kim et al (49) found that patients undergoing colonoscopy were more willing to return than patients undergoing air contrast barium enema $(\mathrm{OR}$ 1.82; $95 \%$ CI 1.07 to 3.09), but not more willing than patients undergoing sigmoidoscopy (OR 1.02; 95\% CI 0.66 to 1.57 ).

\section{Preference of colonoscopy over another modality}

Five studies compared patient preference for colonoscopy versus CT colonography (Table 2). Results were inconsistent; three studies $(40,50,54)$ found that the majority of patients preferred CT colonography (range $58 \%$ to $72 \%$ ) and two studies $(43,53)$ found that the majority of patients preferred colonoscopy to CT colonography.

\section{Pilot study}

We conducted a prospective pilot study of patients 50 to 80 years of age about to undergo screening colonoscopy aimed at assessing patient satisfaction with the experience. Patients were enrolled on the day of the index colonoscopy and completed a mail-back questionnaire two weeks later to assess satisfaction with the colonoscopy experience using a 5-point rating scale $(0=$ not at all to $4=$ very much $)$. The study was approved by the Faculty of Medicine Institutional Review Board of McGill University, Montreal, Quebec, and the research ethics boards of participating institutions. Of the 50 consecutively approached patients, 49 (98\%) (mean age $61.9 \pm 8.5$ years; $57.1 \%$ women) were enrolled and provided data after two-weeks. Twenty-four patients (48.9\%) were 'very much' satisfied, 20 (40\%) were 'quite a bit' satisfied and the mean satisfaction was 3.32 out of a possible 4 .

\section{DISCUSSION}

The literature review found that patient satisfaction with colonoscopy was very high and that most patients were willing to return under the same conditions. The discrepancies among studies may have been due to the wording of the questionnaire items and/or to differences in factors that were not assessed in the questionnaires such as staff attitude, aspects of the endoscopy suite/recovery room and waiting room wait time. These other factors may be more relevant to patient willingness to return than to satisfaction with the colonoscopy itself.

Preference for colonoscopy over other modalities was examined. In three studies $(40,50,54)$, CT colonography was favoured over colonoscopy while the reverse was found in two $(43,53)$. These equivocal findings are relevant given the recent addition of CT colonography as a recommended CRC screening procedure by some of the professional agencies in the United States (55). This newly endorsed modality would not only offer additional screening options to patients, but it would also add other professionals, equipment resources and space to the CRC screening armamentarium. Research efforts that are currently underway may inspire other organizations to include CT colonography as a recommended screening modality $(40,53,56,57)$. Although comparison of colonoscopy with other large bowel procedures was not examined within the same individual, two studies $(42,49)$ concluded a preference for colonoscopy compared with sigmoidoscopy, based on higher scores in the colonoscopy group.

Whereas our focus was not on specific aspects of patient satisfaction, some of the included studies reported proportions of sedated and nonsedated patients according to levels of satisfaction. Regardless of whether all (100\%) patients in a study were sedated or not sedated, moderate to high levels of satisfaction and willingness to return were reported (43,47-51). Moreover, in the study by Rex et al (52), in which patients were randomly assigned to receive sedation or no sedation, similar proportions of 'very satisfied' patients were found in the two study arms. Collectively, these findings suggest that sedation is not associated with patient satisfaction.

The impact of various interventions on improving patient satisfaction with colonoscopy was examined using randomized controlled trial designs. Vignally et al (32) found that a precolonoscopy consultation with a physician was associated with increased patient satisfaction. Bechtold et al (31) found that music in the colonoscopy suite was associated with increased patient satisfaction. In contrast, Bytzer and Lindeberg (30) failed to show that an informational video viewed before the endoscopy procedure was associated with increased patient satisfaction. Whereas several interventions were shown to positively affect patient satisfaction, because some may not be implementable in either a public health care system or a particular endoscopy suite due to limited resources and/or space allocation, we chose to restrict our review to observational studies.

Several strengths and limitations need to be considered in the present literature review. The major limitation of the studies reviewed is that patients who were most dissatisfied with the screening colonoscopy experience (eg, long wait times) may have gone elsewhere to have the procedure performed. However, studies included were restricted to those that assessed levels of patient satisfaction with the present standard of care; interventional studies were not included because implementing an intervention may be difficult in various settings. Higher quality scores were given to studies that included only screening populations because satisfaction is more relevant in the screening compared with the diagnostic context, in which the colonoscopy is likely being used to identify a specific problem. Although only a handful of studies were limited to screening populations, satisfaction levels were high $(40-42,54)$ and comparable with nonscreening settings. Finally, the findings may be generalizable given that patient satisfaction was high irrespective of whether procedures occurred in a universal access, publically funded program or insurance programs requiring copayment.

\section{CONCLUSION}

After reviewing the literature regarding patient satisfaction with colonoscopy as well as our own findings, a few points are noteworthy. As a large bowel screening procedure for CRC, colonoscopy was associated with high levels of patient satisfaction and a willingness to return. Moreover, patients were equally satisfied with colonoscopy and CT colonography, a promising finding given the recent endorsement of CT colonography as a 
recommended CRC screening modality and the accompanying additional resources for CRC screening. Our pilot study findings are also reassuring because, even in the current era of limited resources and constraints under which colonoscopy is performed, most patients were satisfied with the care they received. Inasmuch as screening colonoscopy is advised every 10 years, providing patients with a positive colonoscopy experience is essential to encourage repeat screening.

ACKNOWLEDGEMENTS: This research was funded in part, by the Fonds de recherche en santé du Québec. Lucas Chartier was supported by the Dr Clarke K McLeod Memorial Scholarship Fund and Judith Ann Wright Litvack student research bursaries of the McGill University Faculty of Medicine. Maida J Sewitch is supported as a research scientist of the Canadian Cancer Society through an award from the National Cancer Institute of Canada.

\section{REFERENCES}

1. Canadian Cancer Society/National Cancer Institute of Canada. Canadian Cancer Society Statistics 2008, Toronto, Canada, 2008.

2. Pignone M, Rich M, Teusch SM, Berg AO, Lohr KN. Screening for colorectal cancer in adults at average risk: A summary of the evidence for the US Preventive Services Task Force. Ann Intern Med 2002;137:132-141.

3. Winawer SJ, Zauber AG, Ho MN, et al. Prevention of colorectal cancer by colonoscopic polypectomy. N Engl J Med 1993;329:1977-81.

4. Imperiale TF, Wagner DR, Lin CY, Larkin GN, Rogge JD, Ransohoff DF. Risk of advanced proximal neoplasms in asymptomatic adults according to the distal colorectal findings. N Engl J Med 2000;343:169-74.

5. Ross TM, Ross N. How do I screen for colorectal cancer? Can J Diagn 2003:70-75.

6. Winawer SJ, Stewart ET, Zauber AG, et al. A comparison of colonoscopy and double-contrast barium enema for surveillance after polpyectomy. N Engl J Med 2000;342:1766-72.

7. Lieberman DA, Weiss DG, Bond JH, Ahnen DJ, Garewal H, Chejfec G \& for Veterans Affairs Cooperative Study Group 380. Use of colonoscopy to screen asymptomatic adults for colorectal cancer. N Engl J Med 2000;343:162-8.

8. Feldman GE, McCord CW, Bassett MT, Frieden TR. Screening for colorectal cancer. JAMA 2003;290:191.

9. Leddin D, Hunt R, Champion M, et al. Canadian Association of Gastroenterology and the Canadian Digestive Health Foundation: Guidelines on colon cancer screening. Can J Gastroenterol 2004;18:93-9.

10. Rex DK, Johnson DA, Lieberman DA, Burt RW, Sonnenberg A. Colorectal cancer prevention 2000: Screening recommendations of the American College of Gastroenterology. American College of Gastroenterology. Am J Gastroenterol 2000;95:868-77.

11. Barkun AN, Jobin G, Cousineau G, et al. The Quebec Association of Gastroenterology position paper on colorectal cancer screening 2003. Can J Gastroenterol 2004;18:509-19.

12. Zarychanski R, Chen Y, Bernstein CN, Hébert PC. Frequency of colorectal cancer screening and the impact of family physicians on screening behaviour. CMAJ 2007;177:593-7.

13. Sewitch MJ, Fournier C, Ciampi A, Dyachenko A. Adherence to colorectal cancer screening guidelines in Canada. BMC Gastroenterol 2007;7:39.

14. Harewood GC, Wiersema MJ, Melton LJI. A prospective, controlled assessment of factors influencing acceptance of screening colonoscopy. Am J Gastroenterol 2002;97:3186-94.

15. Dowell J, Hudson H. A qualitative study of medication-taking behaviour in primary care. Fam Pract 1997;14:369-75.

16. Hennekens CH, Buring, JE. Screening. In: Mayrent SL, ed. Epidemiology in Medicine. Boston:Little, Brown and Co, 1987;327-47.

17. Lieberman D. Cost-effectiveness model for colon cancer screening. Gastroenterology 1995;109:1781-90.

18. McQuaid KR, Laine L. A systematic review and meta-analysis of randomized controlled trials of moderate sedation for routine endoscopic procedures. Gastrointest Endosc 2008;67:910-23.
19. Armstrong D, Barkun ANG, Chen Y, et al. Access to specialist gastroenterology care in Canada: The Practice Audit in Gastroenterology (PAGE) wait times program. Can J Gastroenterol 2008;22:155-60.

20. Luck A, Pearson S, Maddem G, Hewett P. Effects of video information on precolonoscopy anxiety and knowledge: A randomised trial. Lancet 1999;354:2032-5.

21. Nicholson FB, Korman MG. Comparison of endoscopic procedures for colorectal cancer screening in women with mammography and Pap smear. Gastrointest Endosc 2004;60:400-7.

22. Cataldo PA. Colonoscopy without sedation. Dis Colon Rectum 1996;39:257-61.

23. Froehlich F, Thorens J, Schwizer W, et al. Sedation and analgesia for colonoscopy: Patient tolerance, pain, and cardiorespiratory parameters. Gastrointest Endosc 1997;45:1-9.

24. Lalos AT, Hovanec-Lalos CA, Weber B. Patient satisfaction with conscious sedation for ambulatory colonoscopy in a community hospital. Gastroenterol Nurs 1997;20:114-7.

25. Wolf RL, Basch CE, Brouse CH, Shmukler C, Shea S. Patient preferences and adherence to colorectal cancer screening in an urban population. Am J Public Health 2006;96:809-11.

26. Ling BS, Moskowitz MA, Wachs D, Pearson B, Schroy PC. Attitudes toward colorectal cancer screening tests. A survey of patients and physicians. J Gen Intern Med 2001;16:822-30.

27. Dominitz JA, Provenzale D. Patient preferences and quality of life associated with colorectal cancer screening. Am J Gastroenterol 1997;92:2171-8.

28. Marshall DA, Johnson FR, Phillips KA, Marshall JK, Thabane L, Kulin NA. Measuring patient preferences for colorectal cancer screening using a choice-format survey. Value Health 2007;10:415-30.

29. Schroy PC, Glick JT, Robinson PA, Heeren T. Screening preferences of patients at familial risk of colorectal cancer. Dig Dis Sci 2007;52:2788-95.

30. Bytzer P, Lindeberg B. Impact of an information video before colonoscopy on patient satisfaction and anxiety - a randomized trial. Endoscopy 2007;39:710-14.

31. Bechtold ML, Perez RA, Puli SR, Marshall JB. Effect of music on patients undergoing outpatient colonoscopy. World J Gastroenterol 2008;12:7309-12.

32. Vignally P, Gentile S, Grimaud F, et al. Pertinence of a precolonoscopy consultation for routine information delivery. Gastroenterol Clin Biol 2007;31;1055-61.

33. Byers T, Levin B, Rothenberger D, Dodd GD, Smith RA. American Cancer Society Guidelines for Screening and Surveillance for Early Detection of Colorectal Polyps and Cancer: Update 1997. CA Cancer J Clin 1997;47:154-60.

34. Elwood JM, Ali G, Schlup MM, et al. Flexible sigmoidoscopy or colonoscopy for colorectal screening: A randomized trial of performance and acceptability. Cancer Detect Prev 1995;19:337-47.

35. Schutz SM, Lee JG, Schmitt CM, Almon M, Baillie J. Clues to patient dissatisfaction with conscious sedation for colonoscopy. Am J Gastroenterol 1994;89:1476-9.

36. Van Ness MM, Chobanian SJ, Winters C Jr, Diehl AM, Esposito RL, Cattau EL Jr. A study of patient acceptance of doublecontrast barium enema and colonoscopy. Which procedure is preferred by patients? Arch Intern Med 1987;147:2175-6.

37. Salmon P, Shah R, Berg S, Williams C. Evaluating customer satisfaction with colonoscopy. Endoscopy 1994;26:342-6.

38. Seow-Choen F, Leong AF, Tsang C. Selective sedation for colonoscopy. Gastrointest Endosc 1994;40:661-4.

39. Waye JD. Quo vadis: Another new colonoscope. Am J Gastroenterol 2007;102:267-8.

40. Gluecker TM, Johnson CD, Harmsen WS, et al. Colorectal cancer screening with CT colonography, colonoscopy, and double-contrast barium enema examination: Prospective assessment of patient perceptions and preferences. Radiology 2003;227:378-84.

41. Nicholson FB, Korman MG. Acceptance of flexible sigmoidoscopy and colonoscopy for screening and surveillance in colorectal cancer prevention. J Med Screen 2005;12:89-95.

42. Marbet UA, Bauerfeind P, Brunner J, Dorta G, Valloton JJ, Delco F. Colonoscopy is the preferred colorectal cancer screening method in a population-based program. Endoscopy 2008;40:650-5.

43. Bosworth HB, Rockey DC, Paulson EK, et al. Prospective comparison of patient experience with colon imaging tests. Am J Med 2006;119:791-9. 
44. Takahashi Y, Tanaka H, Kinjo M, Sakumoto K. Sedation-free colonoscopy. Dis Colon Rectum 2005;48:855-9.

45. Lin OS, Schembre DB, Ayub K, et al. Patient satisfaction scores for endoscopic procedures: impact of a survey-collection method. Gastrointest Endosc 2007;65:775-81.

46. Eckardt AJ, Swales C, Bhattacharya K, et al. Open access colonoscopy in the training setting: Which factors affect patient satisfaction and pain? Endoscopy 2008;40:98-105.

47. Yörük G, Aksöz K, Ünsal B, et al. Colonoscopy without sedation. Turk J Gastroenterol 2003;14:59-63.

48. Lee DW, Chan AC, Wong SK, Li AC, Sze TS, Chung SC. The safety, feasibility, and acceptability of patient-controlled sedation for colonoscopy: Prospective study. Hong Kong Med J 2004;10:84-8.

49. Kim LS, Koch J, Yee J, Halvorsen R, Cello JP, Rockey DC.

Comparison of patients' experiences during imaging tests of the colon. Gastrointest Endosc 2001;54:67-74.

50. Ristvedt SL, McFarland EG, Weinstock LB, Thyssen EP. Patient preferences for CT colonography, conventional colonoscopy and bowel preparation. Am J Gastroenterol 2003;98:578-85.

51. Hoffman MS, Butler TW, Shaver T. Colonoscopy without sedation. J Clin Gastroenterol 1998;26:279-82.
52. Rex DK, Imperiale TF, Portish V. Patients willing to try colonoscopy without sedation: Associated clinical factors and results of a randomized controlled trial. Gastrointest Endosc 1999;49:554-9.

53. Akerkar GA, Yee J, Hung R, McQuaid K. Patient experience and preferences toward colon cancer screening: A comparison of virtual colonoscopy and conventional colonoscopy. Gastrointest Endosc 2001;54:310-15

54. van Gelder RE, Birnie E, Florie J, et al. CT colonography and colonoscopy: Assessment of patient preference in a 5-week follow-up study. Radiology 2004;233:328-37.

55. Levin B, Lieberman DA, McFarland B, et al. Screening and surveillance for the early detection of colorectal cancer and adenomatous polyps, 2008: A joint guideline from the American Cancer Society, the US Multi-Society Task Force on Colorectal Cancer, and the American College of Radiology. CA Cancer J Clin 2008;58:130-60.

56. Summerton S, Little E, Cappell MS. CT colonography: Current status and future promise. Gastroenterol Clin North Am 2008;37:161-89.

57. Schima W, Mang T. CT colonography in cancer detection: Methods and results. Cancer Imaging 2004;4:533-41. 


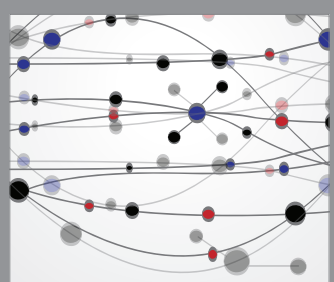

The Scientific World Journal
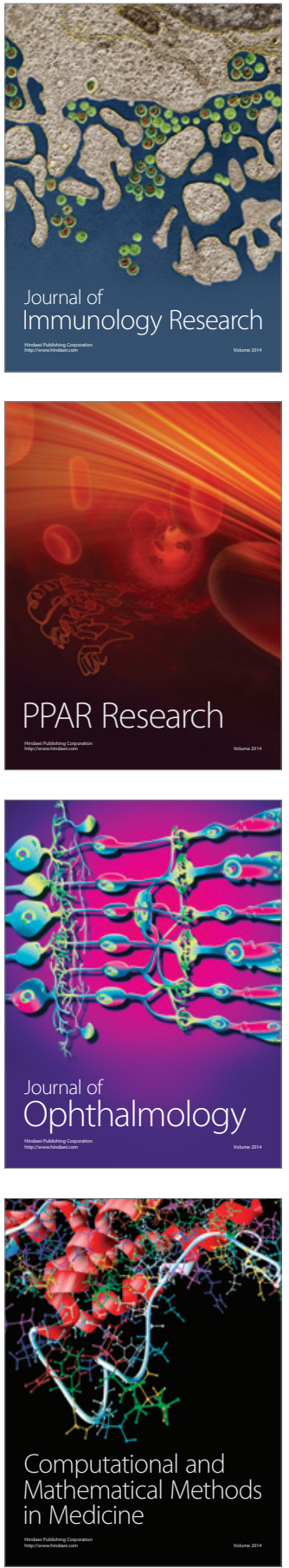

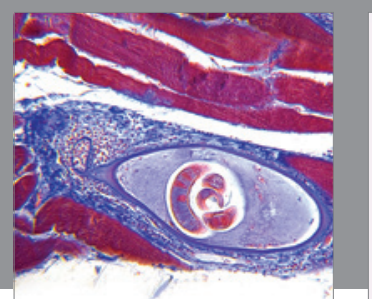

Gastroenterology Research and Practice

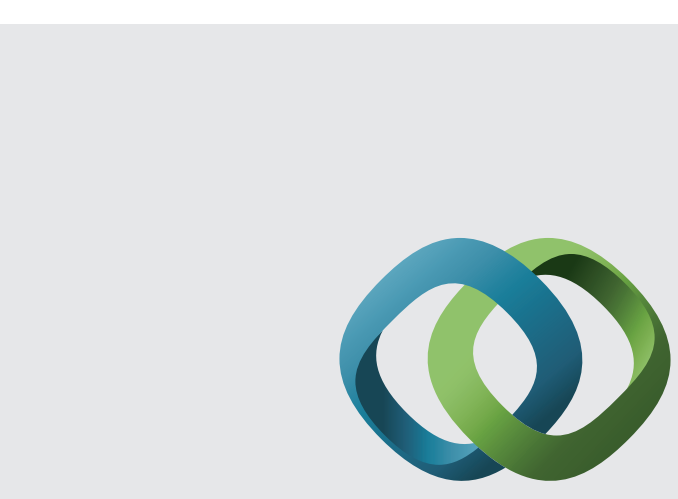

\section{Hindawi}

Submit your manuscripts at

http://www.hindawi.com
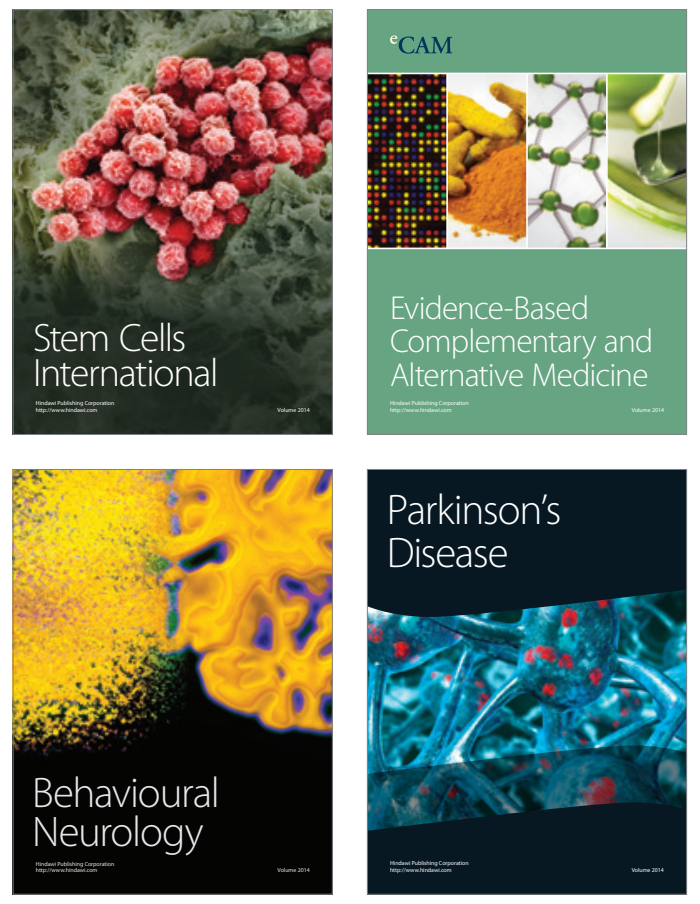
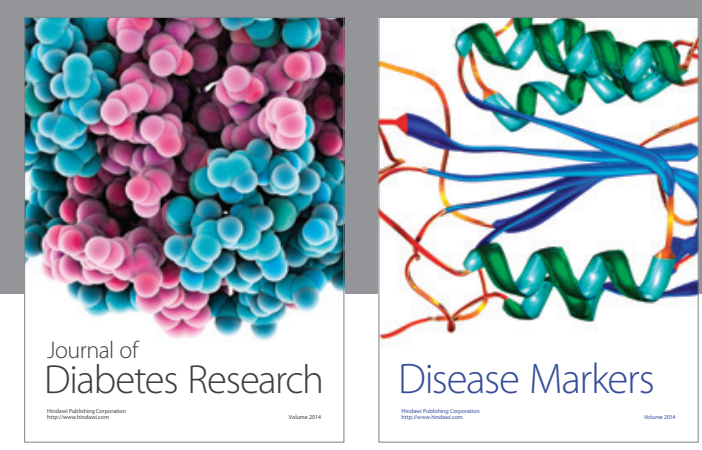

Disease Markers
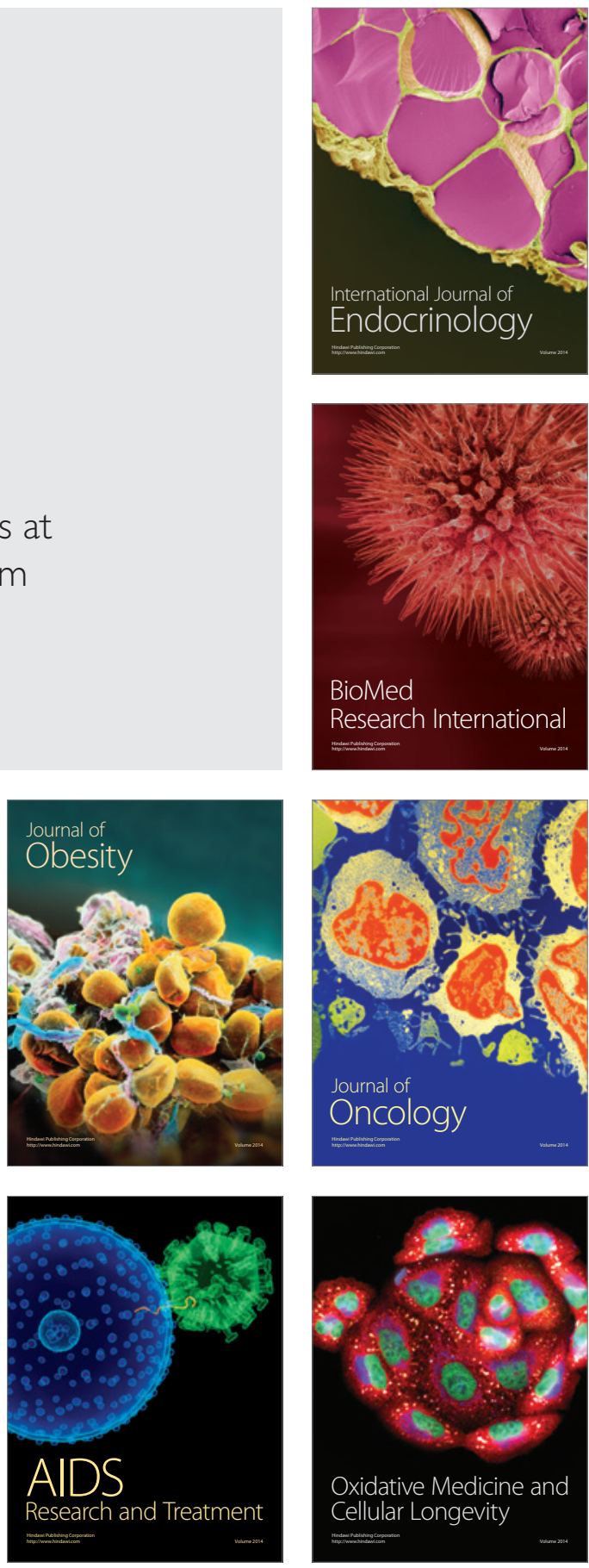